\title{
Retensio Plasenta Ditinjau dari Paritas Ibu dan Anemia di RSUD Kota Prabumulih
}

Desti Widya Astuti

Akademi Kebidanan Rangga Husada Prabumulih

Informasi Artikel :

Diterima : 20 November 2020

Direvisi : 23 Novembe 2020

Disetujui : 03 Desember 2020

*Korespondensi Penulis : destiwidya.29@gmail.com

\section{A B S T R A K}

Mayoritas kasus kematian ibu disebabkan oleh perdarahan saat melahirkan. Perdarahan ini dapat disebabkan oleh atonia uteri 50$60 \%$, retensio plasenta $23-29 \%$, serta robekan jalan lahir $4-5 \%$. Retensio plasenta adalah keadaan dimana plasenta belum lahir dalam waktu setengah jam setelah bayi lahir. Diagnosis ditegakkan berdasarkan adanya plasenta tidak lahir spontan dan tidak yakin apakah plasenta lengkap.Tujuan dari penelitian ini adalah untuk mengetahui hubungan antara paritas ibu dan anemia dengan kejadian retensio plasenta di Rumah Sakit Umum Daerah Kota Prabumulih Tahun 2019. Penelitian ini menggunakan Survey Analitik dengan menggunakan pendekatan Cross Sectional. Popuasi penelitian ini adalah semua ibu yang bersalin di Rumah Sakit Umum Daerah Kota Prabumulih Tahun 2019 yang berjumlah 1712 orang. Jumlah sampel pada penelitian ini adalah 324 responden. Pada analisa univariat diketahui bahwa dari 324 responden didapatkan bahwa ibu yang mengalami retensio plasenta sebanyak 106 responden $(32,7 \%)$ lebih sedikit dari ibu yang tidak mengalami retensio plasenta yaitu sebanyak 218 responden $(67,3 \%)$. Pada analisa univariat diketahui bahwa dari 324 responden didapatkan bahwa ibu dengan paritas resiko tinggi sebanyak 169 responden $(52,2 \%)$ lebih banyak dari ibu yang paritas resiko rendah yaitu sebanyak 155 responden $(47,8 \%)$. Pada analisa univariat diketahui bahwa dari 324 responden didapatkan ibu yang di diagnosa anemia sebanyak 178 responden $(54,9 \%)$ lebih banyak dari ibu yang tidak di diagnosa anemia yaitu sebanyak 146 responden (45,1\%). Analisa Bivariat menunjukan Paritas Ibu mempunyai hubungan yang bermakna dengan kejadian Retensio Plasenta ( $p$ value 0,000$)$ dan Anemia mempunyai hubungan yang bermakna dengan kejadian ( $p$ value 0,00 ). Simpulan dari penelitian ini adalah bahwa ada hubungan yang bermakna antara paritas ibu dan anemia dengan kejadian retensio plasenta di Rumah Sakit Umum Daerah Kota Prabumulih Tahun 2019.

Kata Kunci

: Paritas Ibu, Anemia dan Retensio Plasenta

\section{ABSTRACT}

The majority of maternal deaths are caused by bleeding during childbirth. This bleeding can be caused by uterine atony 50-60\%, $23-29 \%$ retention of the placenta, and 4-5\% tearing of the birth canal. Placental retention is a condition in which the placenta is not born within half an hour after the baby is born. The diagnosis is made based on the presence of a placenta not born spontaneously and not sure whether the placenta is complete. The Object of this research is to know correlation between mother's paritas and anemia with the occurence of retensio placenta in Local General Hospita of Prabumulih City Year 2019. The research used analytic survey by using Cross Sectional approach. The populations of this research were all maternity mothers in Local General Hospital Of Prabumulih City 2019 with total 1712 women. The number of samples in this research are 324 
respondens. In univariate analysis known that 324 respondents taken that mothers who was diagnosed retensio placenta 106 respondents $(32,7 \%)$ it mother who is not diagnosed retensio placenta 218 respondents (67,3\%). In univariate analysis known that 324 respondents taken that mothers with high paritas 169 respondents $(52,2 \%)$ it was lots than those who have low paritas there were 155 respondents $(47,8 \%)$. In univariate analysis known that 324 respondents taken that mothers who had diagnosis of anemia were 178 respondents $(54,9 \%)$ it was lots than those who didn't have anemia diagnosis, they were 146 respondent (45,1\%). Bivariate analysis showed that mother's paritas had significance correlation with the occurence of Retensio Placenta ( $p$ value $0,000)$ and Anemia had significance correlation with the occurence of Retensio Placenta ( $p$ value 0,000). The Conclusion of this that there is significance correlation between Mother's Paritas and Anemia with the occurence of Retensio placenta in Local General Hospital Of Prabumulih City Year 2019.

Keywords : Mother's Paritas, Anemia, and Retensio Placenta

\section{PENDAHULUAN}

Retensio plasenta adalah keadaan dimana plasenta belum lahir dalam waktu setengah jam setelah bayi lahir. Diagnosis ditegakkan berdasarkan adanya plasenta tidak lahir spontan dan tidak yakin apakah plasenta lengkap (Walyani, 2015).

Menurut Kemenkes mayoritas kasus kematian ibu disebabkan oleh perdarahan saat melahirkan. Perdarahan ini dapat disebabkan oleh atonia uteri $50-60 \%$, retensio plasenta $23-29 \%$, serta robekan jalan lahir $4-5 \%$. Selain itu juga dapat disebabkan oleh faktor resiko (Kemenkes,2015).

Faktor predisposisi retensio adalah paritas ibu, plasenta previa, riwayat seksio sesaria, dan riwayat kuretase berulang (Saifuddin, 2009). Faktor presdiposisi lain yaitu anemia, usia, jarak persalinan, penolong persalinan, riwayat manual plasenta, riwayat pembedahan uterus dan destruksi endometrium dari infeksi sebelumnya (Manuaba, 2010).

Terapi untuk retensio atau inkarserasi adalah 35 unit syntocinon (oksitosin) IV yang diikuti oleh usaha pengeluaran secara hati-hati dengan tekanan pada fundus. jika plasenta tidak lahir, usahakan pengeluaran secara manual setelah 15 menit. Jika ada keraguan tentang lengkapnya plasenta, lakukan palpasi sekunder (Walyani, 2015).

\section{METODE PENELITIAN}

Jenis penelitian ini menggunakan metode survey Analitik dengan pendekatan Cross Sectional dimana variabel independen dan variabel dependen dikumpulkan dalam waktu yang bersamaan (Notoatmodjo, 2014). Populasi penelitian ini adalah semua ibu yang melahirkan di Rumah Sakit Umum Daerah Kota Prabumulih pada Tahun 2017 yang berjumlah 1712 (Rekam Medik RSUD Kota Prabumulih,2020). Sampel pada penelitian ini dengan teknik sampel random sampling. Sampel dalam penelitian yaitu 324 orang.

Cara pengambilan sampel dilakukan dengan mengambil data sekunder, data sekunder yaitu data yang didapat dari lembaga instansi. Dalam penelitian ini data sekunder diperoleh dari data rekam medik rumah sakit umum daerah kota prabumulih. Waktu penelitian dilakukan pada bulan April 2020 di RSUD Kota Prabumulih. Analisis data yang digunakan adalah analisis univariat dan analisis bivariat.

\section{HASIL PENELITIAN}

Hasil-hasil penelitian dapat dilihat pada tabeltabel yang disajikan.:

Tabel 1 Hubungan Paritas Dengan Kejadian Retensio Plasenta di Rumah Sakit Umum Daerah Kota Prabumulih Tahun 2019.

\begin{tabular}{|c|c|c|c|c|c|c|c|}
\hline \multirow{3}{*}{$\begin{array}{c}\text { Paritas } \\
\text { Ibu }\end{array}$} & \multicolumn{6}{|c|}{ Kejadian Retensio Plasenta } & \multirow{3}{*}{$\begin{array}{c}P \\
\text { value }\end{array}$} \\
\hline & \multicolumn{2}{|c|}{ Ya } & \multicolumn{2}{|c|}{ Tidak } & \multicolumn{2}{|c|}{ Jumlah } & \\
\hline & $\mathbf{N}$ & $\%$ & $\mathbf{n}$ & $\%$ & $\mathbf{N}$ & $\%$ & \\
\hline $\begin{array}{l}\text { Resiko } \\
\text { Tinggi }\end{array}$ & 73 & 43,2 & 96 & 56,8 & 169 & 100 & \multirow[t]{3}{*}{0,000} \\
\hline $\begin{array}{l}\text { Resiko } \\
\text { Rendah }\end{array}$ & 33 & 21,3 & 122 & 78,7 & 155 & 100 & \\
\hline Jumlah & 106 & 32,7 & 218 & 67,3 & 324 & 100 & \\
\hline
\end{tabular}


Jurnal Kebidanan :Jurnal Medical Science Ilmu Kesehatan Akademi Kebidanan Budi Mulia Palembang Volume.10 No.2, Desember 2020

Berdasarkan hasil analisa bivariat dengan uji statistik menggunakan Chi Square didapatkan hasil $p$ value $=0,000$ lebih kecil dari $\alpha=0,05$ berarti hipotesis yang mengatakan bahwa ada hubungan yang bermakna antara paritas dengan kejadian retensio plasenta terbukti secara statistik.

Tabel 2 Hubungan Anemia dengan Kejadian Retensio Plasenta di Rumah Sakit Umum Daerah Kota Prabumulih Tahun 2019

\begin{tabular}{|c|c|c|c|c|c|c|c|}
\hline \multirow{3}{*}{ Anemia } & \multicolumn{6}{|c|}{ Kejadian Retensio Plasenta } & \multirow{3}{*}{$\begin{array}{c}P \\
\text { value }\end{array}$} \\
\hline & \multicolumn{2}{|c|}{ Ya } & \multicolumn{2}{|c|}{ Tidak } & \multicolumn{2}{|c|}{ Jumlah } & \\
\hline & $\mathbf{n}$ & $\%$ & $\mathbf{n}$ & $\%$ & $\mathbf{N}$ & $\%$ & \\
\hline $\begin{array}{l}\text { Resiko } \\
\text { Tinggi } \\
\end{array}$ & 76 & 23,4 & 102 & 31,5 & 178 & 100 & \multirow[t]{2}{*}{0,00} \\
\hline $\begin{array}{l}\text { Resiko } \\
\text { Rendah }\end{array}$ & 30 & 9,2 & 116 & 35,8 & 155 & 100 & \\
\hline Jumlah & 106 & 32,6 & 218 & 67,4 & 324 & 100 & \\
\hline \multicolumn{8}{|c|}{$\begin{array}{l}\text { Berdasarkan hasil analisa bivariat } \\
\text { an uji statistik menggunakan Chi Square } \\
\text { atkan hasil } p \text { value }=0,000 \text { lebih kecil } \alpha \\
05 \text { berarti hipotesis yang mengatakan } \\
\text { a ada hubungan yang bermakna antara } \\
\text { ia dengan kejadian retensio plasenta } \\
\text { kti secara statistik. }\end{array}$} \\
\hline
\end{tabular}

\section{PEMBAHASAN}

1. Hubungan antara paritas ibu dengan kejadian retensio plasenta di RSUD kota Prabumulih Tahun 2019

Hasil analisa bivariat didapatkan dari 324 responden, 169 responden dengan paritas resiko tinggi terdapat 73 responden $(43,2 \%)$ mengalami retensio plasenta dan 96 responden $(56,8 \%)$ yang tidak mengalami retensio plasenta, sedangkan dari 155 responden yang dengan paritas resiko rendah terdapat 33 responden $(21,3 \%)$ mengalami retensio plasenta dan 122 responden $(78,7 \%)$ yang tidak mengalami retensio plasenta.

Hasil uji statistik menggunakan Chi Square didapatkan hasil $p$ value 0,000 berarti hipotesis yang mengatakan bahwa ada hubungan yang bermakna antara paritas dengan kejadian retensio plasenta terbukti secara statistik.

Hal ini sesuai teori yang menerangkan bahwa risiko retensio plasenta meningkat karena pada setiap kehamilan dan persalinan terjadi perubahan serabut otot pada uterus yang dapat meningkatkan kemampuan pembuluh-pembuluh darah tertanam lebih dalam otot uterus sehingga dapat terjadi retensio plasenta (Manuaba,2010).

Penelitian ini sama seperti yang dilakukan oleh Darmayanti (2012) yang menyatakan bahwa terdapat hubungan antara paritas dengan kejadian retensio plasenta di RSUD Dr. H. Moch Ansari Banjarmasin ( $p$ value 0,000 ) yang artinya ibu dengan paritas resiko tinggi ( jumlah > 3 anak) memiliki risiko lebih besar terjadinya retensio plasenta dibandingkan ibu dengan paritas resiko rendah (jumlah 1-3 anak ).

\section{Hubungan antara anemia dengan kejadian retensio plasenta di RSUD kota Prabumulih Tahun 2019}

Hasil analisa bivariat didapatkan 324 responden, 178 responden yang mengalami anemia terdapat 76 responden $(42,7 \%)$ mengalami retensio plasenta dan 102 responden $(57,3 \%)$ yang tidak mengalami retensio plasenta, sedangkan dari 146 responden yang tidak mengalami anemia terdapat 30 responden ( $20,5 \%)$ mengalami retensio plasenta dan 116 responden $(79,5 \%)$ yang tidak mengalami retensio plasenta. Hasil uji statistik menggunakan Chi Square didapatkan hasil $p$ value 0,000 berarti hipotesis yang menyatakan bahwa ada hubungan yang bermakna antara anemia dengan kejadian retensio plasenta terbukti secara statistik.

Hal ini sesuai teori yang menerangkan bahwa resiko retensio plasenta meningkat pada ibu hamil yang mengalami anemia, dimana anemia dapat menyebabkan kontraksi uterus tidak adekuat untuk melahirkan plasenta, hal inilah yang dapat menyebabkan retensio plasenta (Saifuddin, 2012).

Hasil penelitian ini sejalan dengan hasil penelitian Harlina (2017) yang menyatakan bahwa ada hubungan antara anemia dengan kejadian retensio plasenta di RS DR. R Ismoyo Kendari Tahun 2017 dengan hasil uji Chi Square menunjukkan bahwa nilai $p$ value $=0,038<$ dari nilai $\alpha=0,05$. Yang artinya ibu hamil dengan $\mathrm{Hb}<11$ gr\% lebih 
Jurnal Kebidanan :Jurnal Medical Science Ilmu Kesehatan Akademi Kebidanan Budi Mulia Palembang Volume.10 No.2, Desember 2020

besar terjadinya retensio plasenta dibandingkan ibu hamil dengan $\mathrm{Hb} \geq 11 \mathrm{gr} \%$.

\section{KESIMPULAN}

Berdasarkan hasil penelitian disimpulkan sebagai berikut : Ada hubungan yang bermakna antara paritas ibu dengan kejadian retensio plasenta di RSUD Kota Prabumulih Tahun 2019 dengan nilai $p$ 0,000 , ada hubungan antara yang bermakna antara anemia dengan kejadian retensio plasenta di RSUD Kota Prabumulih Tahun 2019 dengan nilai $p 0,000$.

\section{DAFTAR PUSTAKA}

Akinola,dkk .2013. Manual Removal Of The Placenta Evaluatins of Some Risk Factor and Management Outcome In Tertiary Maternity Unit . A Case Controled Studt Open Journa Of Obstetrica and Gynekoogy. Hal 279284.

Darmayanti.2014. Faktor-Faktor yang Berhubungan dengan Kejadian Retensio Plasenta i RSUD Dr. H. Moch Ansari Saleh Banjarmasin. 1-3.

Harlina.2016. Hubungan Antara Anemia dalam Kehamilan dengan Kejadian Retensio Plsenta di RSUD Dr. $R$ Ismoyo Kendari. 3.

Kemenkes.2014 .http//:google.co.id.penyebabkematian-ibu-di-Indonesia diakses tanggal 14 Februari 2020

Kemenkes.2015 .http//:google.co.id.angkakematian-ibu-di-Indonesia diakses tanggal 14 Februari 2020

Manuaba, I. 2007. Pengantar Kuliah Obstetri. Jakarta: Trans Info Media.

Manuaba, I. 2010. Ilmu Kebidanan. Jakarta: EGC.

Notoatmodjo. 2014. Metodelogi Penelitian Kesehatan. Jakarta: Renieka Cipta.

Nugroho,Taufan .2012 . Patologi Kebidanan . Yogyakarta : Nuha Medika .
Pranoto.2014. Ilmu Kebidanan. Yogyakarta: Yayasan Bina Pustaka.

Rahmawati, A.2011. Perawatan Masa Nifas. Yogyakarta : Fitramaya

Rohani, R.S .2011. Asuhan Kebidanan Pada Masa Persalinan. Jakarta : Salemba Medika.

Rukiyah, A.YdanLiaYulianti. 2010 . Asuhan Patologi Kebidanan. Jakarta : Trans Info Medika.

Saifuddin.2012. Pelayanan Kesehatan Maternal dan Neonatal. Jakarta: Yayasan Bina Pustaka.

Saifuddin, A. 2002. Buku Acuan Nasional Pelayanan Maternal dan Neonatal. Jakarta: EGC.

Saifuddin, A. 2009. Ilmu Kebidanan. Jakarta: YBPSP.

Saifuddin, A.B. 2014. Buku Panduan Praktis Pelayanan Kesehatan Maternal dan Neonatal. Jakarta: YBPSP.

Sari. 2017. Hubungan Umur, Paritas, dan Anemia dengan Kejadian Retensio Plasenta. di RSUD dr.Adjidarmo Rangkasbitung. 3.

Sarwono, P.2010. Ilmu Kebidanan. Jakarta: PT Bina Pustaka.

Sastrawinata, S.2012. Obstetri Patologi Ilmu Kesehatan Reproduksi. Jakarta: EGC.

Sulistyawati,Ari,dkk.2010.Asuhan

Kebidanan Pada Ibu Bersalin. Jakarta : Salemba Medika.

Tarwoto .2007. Buku Saku Anemia Pada Ibu Hamil, Konsep dan Penatalaksanaannya . Jakarta : Trans Info Media .

Tiarahma, R . 2011 . Konsep Kebidanan. Edisi 1. Jakarta : EGC .

Varney, H.2016. Ilmu Kebidanan. Jakarta: EGC. 
